\title{
Activation of human smooth muscle BK channels by hydrochlorothiazide requires cell integrity and the presence of BK $\beta 1$ subunit
}

\author{
Pedro MARTíN ${ }^{1, *}$, Melisa MONCADA ${ }^{1}$, Guruprasad KUNTAMALLAPPANAVAR ${ }^{2}$, Alex M DOPICO ${ }^{2}$, Verónica MILESI $^{1}$ \\ 1 IIFP, UNLP, CONICET - Instituto de estudios Inmunológicos y Fisiopatológicos, Universidad Nacional de La Plata, Consejo Nacional de \\ Investigaciones Científicas y Tecnológicas, La Plata, Argentina. 47 y 115 S/N, La Plata (1900), Buenos Aires, Argentina; ${ }^{2}$ Department \\ of Pharmacology, College of Medicine, The University of Tennessee Health Science Center, 71 South Manassas St, Memphis, TN, \\ 38103, USA
}

\begin{abstract}
Thiazide-like diuretics are the most commonly used drugs to treat arterial hypertension, with their efficacy being linked to their chronic vasodilatory effect. Previous studies suggest that activation of the large conductance voltage- and $\mathrm{Ca}^{2+}$-dependent $\mathrm{K}^{+}(\mathrm{BK})$ channel $(\mathrm{Slo}$ 1 , MaxiK channel) is responsible for the thiazide-induced vasodilatory effect. But the direct electrophysiological evidence supporting this claim is lacking. BK channels can be associated with one small accessory $\beta$-subunit $\left(\beta_{1}-\beta_{4}\right)$ that confers specific biophysical and pharmacological characteristics to the current phenotype. The $\beta 1$-subunit is primarily expressed in smooth muscle cells (SMCs). In this study we investigated the effect of hydrochlorothiazide (HCTZ) on BK channel activity in native SMCs from human umbilical artery (HUASMCs) and HEK293T cells expressing the BK channel (with and without the $\beta 1$-subunit). Bath application of HCTZ (10 $\mu$ mol/L) significantly augmented the BK current in HUASMCs when recorded using the whole-cell configurations, but it did not affect the unitary conductance and open probability of the BK channel in HUASMCs evaluated in the inside-out configuration, suggesting an indirect mechanism requiring cell integrity. In HEK293T cells expressing BK channels, HCTZ-augmented BK channel activity was only observed when the $\beta_{1}$-subunit was co-expressed, being concentration-dependent with an $\mathrm{EC}_{50}$ of $28.4 \mu \mathrm{mol} / \mathrm{L}$, whereas membrane potential did not influence the concentration relationship. Moreover, HCTZ did not affect the BK channel current in HEK293T cells evaluated in the inside-out configuration, but significantly increases the open probability in the cell-attached configuration. Our data demonstrate that a $\beta_{1}$-subunit-dependent mechanism that requires SMC integrity leads to HCTZ-induced BK channel activation.
\end{abstract}

Keywords: thiazide; hydrochlorothiazide; BK channel; Slo1; $\beta_{1}$-subunit; vascular smooth muscle cells; human umbilical artery; patchclamp electrophysiology

Acta Pharmacologica Sinica (2018) 39: 371-381; doi: 10.1038/aps.2017.133; published online 30 Nov 2017

\begin{abstract}
Introduction
Thiazide diuretics remain as one of the drugs most commonly used to treat systemic arterial hypertension. In particular, hydrochlorothiazide (HCTZ) is one of the first-line antihypertensive therapy drugs ${ }^{[1]}$. HCTZ and related agents exert antihypertensive effects by primarily acting on the kidney, where these drugs block the $\mathrm{Na}^{+} / \mathrm{Cl}^{-}$cotransporter (NCC) and thus produce acute diuresis ${ }^{[2]}$. However, long-term antihypertensive therapy with thiazides has been linked to the agents' ability to lower vascular resistance rather than to their diuretic action $^{[2,3]}$. Remarkably, despite 58 years of demonstrated anti-
\end{abstract}

\footnotetext{
${ }^{*}$ To whom correspondence should be addressed.

E-mail pedromartin@biol.unlp.edu.ar

Received 2017-04-24 Accepted 2017-08-28
}

hypertensive effectiveness, the precise mechanism(s) by which HCTZ and related thiazides evoke vasodilation and therefore reduce vascular resistance are not fully characterized.

Thiazide-induced vasorelaxation has been well documented through in vivo and ex vivo experiments in humans ${ }^{[4-6]}$ and other species $^{[5,7-9]}$. Although studies have established that thiazide-induced vasodilation contributes to the clinical benefit of these agents in chronically treated hypertensive patients, several studies have shown that such thiazide action is independent of NCC blockade ${ }^{[3,10,11]}$. Different mechanisms have been proposed to mediate thiazide-induced artery dilation by targeting smooth muscle cells, including activation of large conductance, voltage- and $\left[\mathrm{Ca}^{2+}\right]_{\mathrm{i}}$-gated potassium $(\mathrm{BK})$ channels ${ }^{[4,5,7,8,12]}$, inhibition of voltage-operated calcium channels (VOCCs $)^{[5,7,8,13]}$ and/or inhibition of the RhoA/Rho kinase 
pathway ${ }^{[9]}$. The latter would induce a $\mathrm{Ca}^{2+}$ desensitization of the smooth muscle contractile machinery. Making the overall scenario more complex, it has been argued that the relative contribution of each of the proposed mechanisms to thiazideinduced vasodilation depends on the species from which vascular tissue was obtained for ex vivo assays ${ }^{[5]}$.

The importance of BK channels in the regulation of vascular smooth muscle cell (VSMC) contractility, peripheral resistance and blood pressure has been extensively established ${ }^{[14,15]}$. These channels are activated by membrane depolarization and/or an increase in intracellular $\mathrm{Ca}^{2+}$ concentration. Since both events are associated with VSMC contraction and BK channel activation, the evoked outward $\mathrm{K}^{+}$current acts as a negative feedback mechanism on VSMC contraction, thereby favoring VSMC relaxation ${ }^{[15,16]}$. Moreover, several studies have suggested that BK channel activity is altered in hypertension (see ${ }^{[17]}$ and $^{[18]}$ reviews for more detail). Thus, the activation of this ion channel has emerged as a novel molecular target for treating diseases where increased tone and/or contractility of smooth muscle play a relevant pathophysiological role, such as hypertension ${ }^{[19]}$.

In most mammalian tissues, native BK channels are homotetramers of pore-forming a-subunits (encoded by the KCNMA1 gene, also named Slo1) that can be associated with one of four auxiliary $\beta$-subunits (encoded by KCNMB1-4 genes) ${ }^{[20-25]}$. Unlike $\alpha$-subunits, $\beta$-subunits do not form functional channels but modify several gating processes ${ }^{[26-28]}$. The differential expression of auxiliary subunits in different cell types explains the multiplicity of functions and regulatory mechanisms of BK channels. In VSMCs, the $\beta_{1}$-subunit is a main partner of the BK channel ${ }^{[25,29]}$. Several studies have shown that endogenous and exogenous compounds can modulate BK channels through $\beta$-subunits ${ }^{[30-33]}$. Additionally, mutations in the $\beta_{1}$-subunit that confer a gain in BK activity are associated with the reduced prevalence of hypertension in humans ${ }^{[34]}$, and the opposite effect occurs in the case of a loss of function mutation $^{[35]}$.

HCTZ did not activate BK channels in skeletal muscle and BK channel a-subunits expressed in HEK cells, two preparations in which the functional expression of $B K \beta_{1}$ is negligible $^{[36,37]}$. Moreover, the hypothesis that the activation of vascular smooth muscle BK channels, which contain $\beta_{1}$-subunits, is involved in HCTZ-induced vasodilation is supported by ex vivo experiments in which this effect is abolished in the presence of BK channel inhibitors ${ }^{[5,8,12]}$. The lack of electrophysiological studies on VSMCs makes it difficult to establish whether HCTZ-induced BK activation reflects a direct drug interaction with channel subunits or indirect drug interactions, i.e., requiring additional cell signals. This question requires electrophysiological studies on VSMCs using different patchclamp configurations under controlled conditions of voltage and $\left[\mathrm{Ca}^{2+}\right]_{\mathrm{i}}$.

In the present study, using patch-clamp electrophysiology, we determined the effects of HCTZ on (i) BK channels from native human umbilical artery smooth muscle cells (HUASMCs) in "whole cell" (WCR) and cell-free, "inside-out" (IO) configurations and (ii) recombinant BK (slo1) channels with or without $\beta_{1}$-subunits co-expressed in HEK293T cells. These results demonstrated that HCTZ effectively induces BK channel activation, and this effect requires both cell integrity and the presence of $\beta_{1}$-subunits.

\section{Materials and methods}

\section{Smooth muscle cell isolation for patch-clamp experiments}

Umbilical cords were obtained from normal term pregnancies after vaginal and cesarean deliveries. The umbilical cords were placed in a transport solution with the following composition (in mmol/L): $130 \mathrm{NaCl}, 4.7 \mathrm{KCl}, 1.17 \mathrm{KH}_{2} \mathrm{PO}_{4}, 1.16$ $\mathrm{MgSO}_{4}, 24 \mathrm{NaCO}_{3} \mathrm{H}$, and $2.5 \mathrm{CaCl}_{2}, \mathrm{pH} 7.4$ at $4{ }^{\circ} \mathrm{C}$. The umbilical cords were immediately transferred to the laboratory, stored at $4^{\circ} \mathrm{C}$ and used within the next $24 \mathrm{~h}$. All procedures were performed in accordance with the Declaration of Helsinki (1975).

Human umbilical arteries (HUAs) were dissected from Wharton's jelly just prior to cell isolation. HUA smooth muscle cells (HUASMCs) were isolated as previously described ${ }^{[38]}$, with further modifications to diminish the enzyme content in the dissociation medium $(\mathrm{DM})^{[32]}$. Briefly, a segment of HUA was cleaned of any residual connective tissue (Wharton's jelly), cut into small strips and placed for $15 \mathrm{~min}$ in DM containing the following (in mmol/L): $140 \mathrm{NaCl}, 5 \mathrm{KH}_{2} \mathrm{PO}_{4}, 5 \mathrm{MgCl}_{2}, 6$ glucose, and 5 HEPES; the $\mathrm{pH}$ was adjusted to 7.4 with $\mathrm{NaOH}$. Vessel strips were subsequently placed in DM containing 3 $\mathrm{mg} / \mathrm{mL}$ collagenase type I for $15-30 \mathrm{~min}$, with gentle agitation at $35^{\circ} \mathrm{C}$. After the incubation period, the strips were washed with DM, and single HUASMCs were obtained by gentle aspiration of the tissue through a Pasteur pipette to render cell dispersion. The supernatant containing the isolated cells was stored at room temperature $\left(\sim 22^{\circ} \mathrm{C}\right)$ until further use. Immediately prior to electrophysiological recordings, HUASMCs were allowed to settle onto the coverglass bottom of a 3-mL experimental chamber. Only well-relaxed, spindle-shaped smooth muscle cells were used for patch-clamp electrophysiology. Data were collected within 4-6 h after cell isolation.

\section{Clones and transient transfection}

HEK293T cells were grown in Dulbecco's modified Eagle's medium (DMEM) supplemented with 10\% fetal bovine serum (FBS) and subsequently split when reaching $70 \%-80 \%$ confluence. The pcDNA3 plasmids harboring the human Slo1 a-subunit (A\#U11058), the auxiliary $\beta_{1}$-subunit (A\#AF035046) and enhanced green fluorescent protein (eGFP) cDNAs were transfected into HEK cells using FuGene 6 (Promega , Madison, WI, USA) and transiently expressed. Transfections were performed in HEK cells grown in 30-mm Petri dishes using cDNAs encoding the a-subunits alone or both $\alpha-$ and $\beta_{1}$-subunits. The $\alpha$ - and $\beta_{1}$-subunits were mixed at 1:3 molar ratios to ensure that all $\alpha$-subunits were saturated with $\beta_{1}$-subunits (total amount of DNA: $2.5 \mu \mathrm{g}$ distributed in 0.5, 0.7 and $1.3 \mu \mathrm{g}$ of plasmids containing eGFP, $\alpha$-subunits and $\beta_{1}$-subunits, respectively). When a-subunits were transfected alone, $\beta_{1}$ cDNA was replaced with empty plasmid. After transfection, the cells were cultured for $18 \mathrm{~h}$. The electro- 
physiological measurements were performed 18-24 h after transfection. BK $a$ and $\beta_{1}$ clones were kind gifts of Dr Carlos GONZÁLEZ (CINV, Chile). The eGFP clone and vector were kindly provided by Dr J RAINGO (IMBICE, Argentina).

\section{Electrophysiology}

Isolated cells were observed using a mechanically stabilized inverted epifluorescence microscope (Arcano XYL 403 YAT PLAN, China) equipped with a $40 \times$ objective lens. Test solutions were applied through a multibarreled pipette positioned close to the target cell (approximated $1 \mathrm{~mm}$ ), which enabled bathing the cell or the pipette tip (in the inside-out configuration) with the test solution for only $5 \mathrm{~s}$. The perfusion rate was approximately $1 \mathrm{~mL} / \mathrm{min}$. After each experiment on a single cell, the experimental chamber was replaced with another containing a new sample of cells. All experiments were performed at room temperature $\left(\sim 22^{\circ} \mathrm{C}\right)$. For all experimental data included in the present study, we prolonged the exposure time to HCTZ to at least 15 min to ensure drug permeation, reflecting its poor lipophilicity. The concentration-response curve to HCTZ (10-300 $\mu \mathrm{mol} / \mathrm{L})$ in HEK293T cells was constructed by applying a single HCTZ concentration to each cell since it took at least $15 \mathrm{~min}$ for HCTZ to increase channel activity.

The standard tight-seal IO and WCR configurations of the patch-clamp technique ${ }^{[39]}$ were used to record single-channel and macroscopic currents, respectively. Glass pipettes were pulled from WPI PG52165-4 glass on a two-stage vertical micropipette puller (PP-83, Narishige Scientific Instrument Laboratories, Tokyo, Japan). Pipette resistance ranged from 1.7 to $3.5 \mathrm{M} \Omega$ when filled with electrode solution. All currents were filtered with a 4-pole low-pass Bessel filter at $2 \mathrm{kHz}$ (Axopatch 200A amplifier, Axon Instruments, Foster City, CA, USA) and digitized (Digidata 1440, Molecular Devices, Sunnyvalle, CA, USA) at $20 \mathrm{kHz}$. Recordings were stored on a computer hard disk for subsequent analysis.

\section{Single-channel recordings}

Single-channel currents were recorded in the inside-out configuration (IO) in HUASMCs and the cell-attached configuration (CA) in HEK293T cells co-transfected with the a- and $\beta_{1}$-subunits of the BK channel. Voltage-clamp recordings (up to $30-60 \mathrm{~s}$ ) were obtained at different membrane potentials to measure the single channel current amplitude and steady-state activity, which results from the product of the single channel open probability (Po) and the number of functional channels in the membrane patch $(\mathrm{N})$. Identification of BK channel presence in the patch was based on its unitary conductance value, voltage-dependent activity and activation by an increase in intracellular $\mathrm{Ca}^{2+}$ concentration, as previously described ${ }^{[40]}$. The control pipette solution used for single-channel recordings contained the following components (in mmol/L): $140 \mathrm{KCl}, 0.5$ $\mathrm{MgCl}_{2}$, $10 \mathrm{HEPES}, 6$ glucose, and $1 \mathrm{CaCl}_{2}$; the $\mathrm{pH}$ was adjusted to 7.4 with $\mathrm{KOH}$. The bath solution (BS) contained the following components (in mmol/L): $140 \mathrm{KCl}, 0.5 \mathrm{MgCl}_{2}, 0.4 \mathrm{CaCl}_{2}$, 10 HEPES, 6 glucose, and 1 EGTA; the $\mathrm{pH}$ was adjusted to 7.4 with $\mathrm{KOH}$. The free $\mathrm{Ca}^{2+}$ concentration was calculated as 50 $\mathrm{nmol} / \mathrm{L}$ using Maxchelator software from Stanford University (http:/ / maxchelator.stanford.edu).

HCTZ's action on BK channels was examined by directly adding the adequate drug quantity to the BS to reach the desired final concentration. Single-channel currents were analyzed using Clampfit software (Molecular Devices, version 10.3). Steady-state activity (NPo) was derived from the equation below, where $\mathrm{N}$ is the number of single channels present in each patch.

$$
N P o=\frac{\sum_{j=1}^{n} j t_{j}}{T}
$$

where $T$ is the recording duration and $t_{j}$ is the time spent with $j=1,2,3, \ldots n$ channels open. Stationary conditions of single channel recordings were controlled by plotting the NPo values calculated for intervals of $30 \mathrm{~s}$ of recording as a function of time (i.e., a stability plot).

\section{Whole-cell recordings in HUASMCs}

Whole-cell current stability was monitored by applying successive $500 \mathrm{~ms}$ voltage steps, from a holding potential of -50 $\mathrm{mV}$ to a test potential of $+40 \mathrm{mV}$. Thus, cells in which the current amplitude did not remain constant in time were discarded. After the current was stabilized, the same voltageclamp step protocol was applied under control (solvent) conditions or in the presence of HCTZ. A voltage-clamp step protocol, including $500 \mathrm{~ms}$ voltage steps spaced $10 \mathrm{mV}$ between -70 and $+70 \mathrm{mV}$ from a holding potential of $-50 \mathrm{mV}$, was applied under control conditions and in the presence of HCTZ for further current amplitude-voltage relationship ( $I-V$ ) analysis. The pipette solution contained the following components (in mmol/L): $130 \mathrm{KCl}, 10 \mathrm{HEPES}, 0.1 \mathrm{EGTA}, 0.1 \mathrm{CaCl}_{2}, 1$ $\mathrm{MgCl}_{2}$, and $5 \mathrm{ATP}-\mathrm{Na}_{2}$; the $\mathrm{pH}$ was adjusted to 7.4 with $\mathrm{KOH}$. The BS contained the following components (in mmol/L): 130 $\mathrm{NaCl}, 5.4 \mathrm{KCl}, 1.2 \mathrm{MgCl}_{2}, 2.5 \mathrm{CaCl}_{2}, 5$ HEPES, 6 glucose, and 5 4-aminopirydine (4-AP); the $\mathrm{pH}$ was adjusted to 7.4 with $\mathrm{HCl}$. The compound 4-AP was added to block Kv channels, which have been detected in HUASMCs ${ }^{[41]}$. Cell membrane capacitance was calculated from the capacity current obtained from the recording of a single 6-ms voltage step from a holding potential of $-50 \mathrm{mV}$ to $-60 \mathrm{mV}$. The mean capacitance and series resistance of the recorded HUASMCs were $24.8 \pm 2.0 \mathrm{pF}$ and 3.1 $\pm 0.3 \mathrm{M} \Omega$, respectively.

\section{Inside-Out macroscopic current recordings in heterologously expressed BK channels}

Macroscopic currents of recombinant BK channels expressed in HEK293T cells were recorded using the IO configuration. Current stability was monitored by applying successive 150 ms voltage steps (from a holding potential of $0 \mathrm{mV}$ to a test potential of $+90 \mathrm{mV}$ ). Cells in which the current amplitude did not remain constant in time were discarded. The same voltage-clamp step protocol was applied under control conditions and in the presence of HCTZ. After current stabilization, a voltage-clamp step protocol, including a family of $150 \mathrm{~ms}$ 
voltage steps spaced $20 \mathrm{mV}$ between -90 and $190 \mathrm{mV}$ from a holding potential of $0 \mathrm{mV}$ followed by a $50 \mathrm{~ms}$ voltage step to $-150 \mathrm{mV}$, was applied under control conditions and in the presence of 10,30 and $100 \mu \mathrm{mol} / \mathrm{L} \mathrm{HCTZ}$ for $I-V$ relationship analysis. Since channel expression (estimated by current amplitude) was extremely variable and the current saturated the amplifier at the more positive potentials examined in most of the evaluated cells, the current values were normalized to the control current obtained at $+130 \mathrm{mV}$. The pipette and bath solutions were identical to those used in the IO experiments in HUASMCs.

\section{Whole-cell current recordings in heterologously expressed $\mathrm{BK}_{\mathrm{ca}}$ channels}

The effects of HCTZ on whole-cell currents mediated by BK channel-forming slo1 proteins (a-subunit) expressed in HEK293T cells with and without the $\beta 1$-subunit were examined. Current stability was monitored by applying successive $100 \mathrm{~ms}$ voltage steps (from a holding potential of $-50 \mathrm{mV}$ to a test potential of $+60 \mathrm{mV}$ ), discarding cells in which the current amplitude did not remain constant in time. The same voltage-clamp step protocol was applied under control conditions or in the presence of HCTZ. After current stabilization, a voltage-clamp step protocol, including a family of $100 \mathrm{~ms}$ voltage steps spaced $10 \mathrm{mV}$ between -60 and $+90 \mathrm{mV}$ from a holding potential of $-50 \mathrm{mV}$, was applied under control conditions and in the presence of 10, 30, 100 and $300 \mu \mathrm{mol} / \mathrm{L} \mathrm{HCTZ}$ to conduct $I-V$ plots. Since channel expression was extremely variable and the current saturated the amplifier at the more positive potentials examined in most of the evaluated cells, current values were normalized to the control values obtained at $+90 \mathrm{mV}$. The pipette solution contained the following components (in mmol/L): $130 \mathrm{KCl}, 10 \mathrm{HEPES}, 1$ EGTA, $0.4 \mathrm{CaCl}_{2}, 1$ $\mathrm{MgCl}_{2}$, and $5 \mathrm{ATP}-\mathrm{Na}_{2}$; the $\mathrm{pH}$ was adjusted to 7.3 with $\mathrm{KOH}$. The BS contained the following components (in $\mathrm{mmol} / \mathrm{L}$ ): 130 $\mathrm{NaCl}, 5.4 \mathrm{KCl}, 1$ EGTA, $1.2 \mathrm{MgCl}_{2}, 0.0094 \mathrm{CaCl}_{2}, 5$ HEPES, and 6 glucose; the $\mathrm{pH}$ was adjusted to 7.4 with $\mathrm{NaOH}$. Both solutions contained a nominal free $\mathrm{Ca}^{2+}$ concentration of $50 \mathrm{nmol} /$ $\mathrm{L}$, calculated using Maxchelator. The mean series resistance of the recorded HEK293T cells was $2.7 \pm 0.2 \mathrm{M} \Omega$.

\section{Drugs and reagents used}

HCTZ, 4-AP, EGTA, $\mathrm{Na}_{2} \mathrm{ATP}$ and collagenase were purchased from Sigma Chemical Co (St Louis, USA). All other reagents, including DMEM medium and FBS, were of analytical grade and purchased from local suppliers. HCTZ was dissolved in dimethyl sulfoxide (DMSO). Fresh aliquots of stock solutions of HCTZ in DMSO were added to the bath solution on the day of the experiment. Appropriate amounts of DMSO were added to all control solutions without HCTZ.

\section{Statistics}

The results are expressed as the means \pm standard error of the mean. Paired Student's $t$ tests were used to compare two groups. ANOVA was used to compare more than two groups. In all cases, a $P$ value less than 0.05 was considered as statisti- cally significant. The concentration-response curve data for BK channel activation by HCTZ were fitted using GraphPad Prism (version 5.03) to a Hill relationship with a variable slope. The equation used for this fit is:

$$
\text { Current increase }=\text { Bottom }+\frac{\text { Top }- \text { Bottom }}{1+10^{\left.\left(\log E C_{50}-x\right) \times \text { Hill slope }\right)}}
$$

where $\mathrm{EC}_{50}$ is the concentration of agonist that gives a response halfway between bottom and top, Hill slope describes the steepness of the curves, and top and bottom are plateaus of current increase. In the present study, we used the parameter $\mathrm{p} D_{2}$, which is the $-\log \mathrm{EC}_{50}$. The fitting parameters at different voltages were compared using the extra sum of squares principle ( $F$ method available in GraphPad Prism).

\section{Results}

Hydrochlorothiazide activates whole-cell BK current in human umbilical artery smooth muscle cells (HUASMCs)

Based on the ex vivo results from Calder et al ${ }^{[8,12]}$ and Pickkers et a ${ }^{[4,7]}$, BK channel activation was postulated as the mechanism underlying vasodilation mediated by thiazide-like diuretics. However, the effect of HCTZ on the BK currents from native vascular smooth muscle cells has not actually been evaluated. Furthermore, when this diuretic was tested on skeletal muscle cells and HEK cells expressing the a-subunit of this channel ${ }^{[36,37]}$, it failed to activate BK channels in both native and heterologous systems in the absence of any $\beta$-subunit. Thus, we evaluated the effect of HCTZ in freshly dissociated HUASMCs as a model of human VSMCs in which the BK channel is associated with the $\beta_{1}$-subunit ${ }^{[32]}$ and involved in the regulation of the basal tone ${ }^{[42]}$. We obtained the isolated voltage-activated macroscopic BK currents from HUASMCs in the standard patch-clamp WCR configuration as previously described ${ }^{[32,42]}$ and examined the effect of HCTZ on these cells (Figure 1). The data demonstrated that after $7 \mathrm{~min}$ of bath (extracellular) application of $10 \mu \mathrm{mol} / \mathrm{L} \mathrm{HCTZ}$, the amplitude of the outward whole-cell current was significantly augmented at membrane potential values between 20 and $70 \mathrm{mV}$ (Figure 1; $P<0.05)$. The effect of HCTZ was fully reversed upon drug washout with solvent-containing bath solution, demonstrating that $10 \mu \mathrm{mol} / \mathrm{L} \mathrm{HCTZ}$ is able to activate BK channels in human VSMCs.

HCTZ failed to modulate BK channel activity in the absence of cell integrity

To determine whether the HCTZ-induced increased ionic BK current in HUASMCs was due to direct drug action on the BK channel proteins or required cell integrity and intact signaling, we next examined the effect of HCTZ on BK currents at a single channel resolution using the IO configuration of the patchclamp technique. Thus, we recorded steady-state channel activity (NPo; see methods) at a constant voltage $(+40 \mathrm{mV})$ in the presence or absence of $10 \mu \mathrm{mol} / \mathrm{L} \mathrm{HCTZ}$. Interestingly, in this cell-free condition, HCTZ failed to modulate channel function: neither unitary current amplitude (Figure $2 B, P>0.05$ ) nor NPo was modified by HCTZ concentrations that increased the 


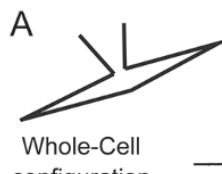
configuration
Control
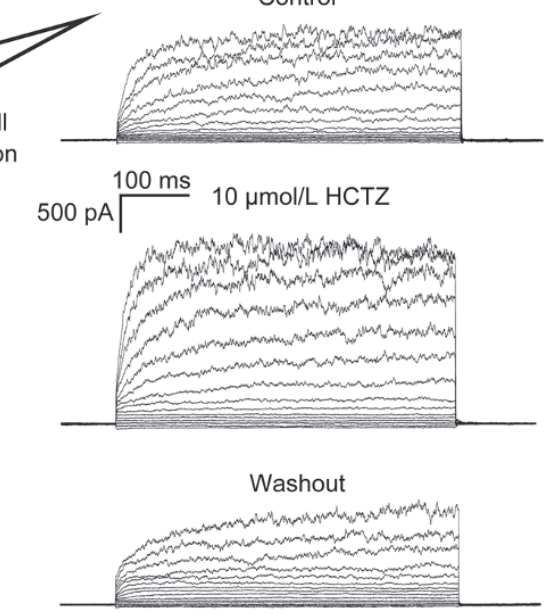

Washout

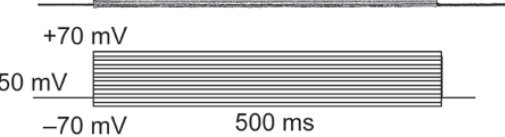

B

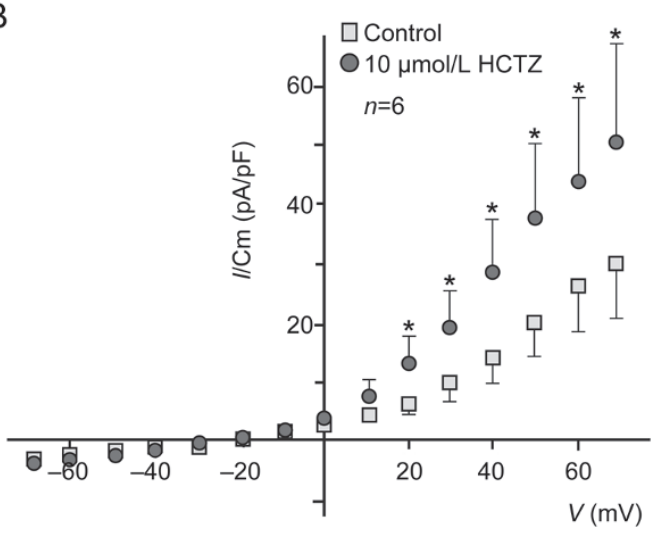

Figure 1. Hydrochlorothiazide ( $\mathrm{HCTZ}$ ) increases the large-conductance voltage- and $\mathrm{Ca}^{2+}$-activated $\mathrm{K}^{+}(\mathrm{BK})$ channel component of whole-cell (WC) $\mathrm{K}^{+}$ currents in human umbilical artery smooth muscle cells (HUASMCs). (A) Superimposed representative recordings of WC currents of HUASMCs (recorded in $5 \mathrm{mmol} / \mathrm{L} 4$-aminopyridine) obtained by applying $10 \mathrm{mV}$ voltage steps from $-70 \mathrm{mV}$ to $+70 \mathrm{mV}$ from a holding potential of $-50 \mathrm{mV}$ in control conditions, after $7 \mathrm{~min}$ of $10 \mu \mathrm{mol} / \mathrm{L} \mathrm{HCTZ}$ perfusion and after washout. (B) Mean current density vs voltage $(I / \mathrm{Cm}-V)$ curves, corresponding to the control conditions and after $7 \mathrm{~min}$ of $10 \mu \mathrm{mol} / \mathrm{L} \mathrm{HCTZ}$ perfusion obtained in the same conditions as in a) ( $n=6$ cells from 3 umbilical cord donors). The symbol * indicates statistically significant difference from control (paired $t$ test, $P<0.05$ ).

macroscopic BK current (Figure 2C, P>0.05). Collectively, the results shown in Figures 1 and 2 indicate that HCTZ requires cell integrity to increase BK currents.

HCTZ-mediated activation of recombinant BK channels in a mammalian heterologous system requires cell integrity and the presence of BK regulatory $\beta_{1}$-subunits

The results shown above demonstrate that HCTZ is able to activate BK channels in HUASMCs. In contrast, this drug failed to activate BK channels in skeletal muscle and HEK cells expressing only the a-subunit ${ }^{[36,37]}$. Thus, since endogenous $\beta_{1}$-subunits are highly expressed in vascular smooth muscle cells but not in skeletal muscle cells or HEK cells, we hypothesized that the $\beta_{1}$-subunit was necessary for HCTZ-induced BK channel activation in HUASMCs ${ }^{[21,25,29]}$. To test this hypothesis, we expressed the channel a-subunit in HEK293T cells with or without the $\beta_{1}$-subunit and examined the effect of HCTZ on these cells using the WCR configuration. Consistent with our hypothesis, HCTZ failed to modulate BK channel activity in the absence of auxiliary subunits (Figure $3, P>0.05$ ). In contrast, HCTZ significantly increased the ionic current mediated by $a+\beta_{1}$ heteromeric channels after 10-15 min of application (Figure 4A, B; $P<0.05$ ).

Next, we studied the HCTZ-induced BK activation in the
A

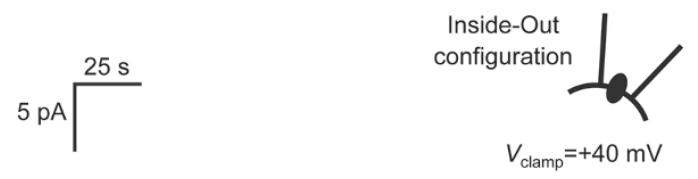

Control

$10 \mu \mathrm{mol} / \mathrm{L} \mathrm{HCTZ}$
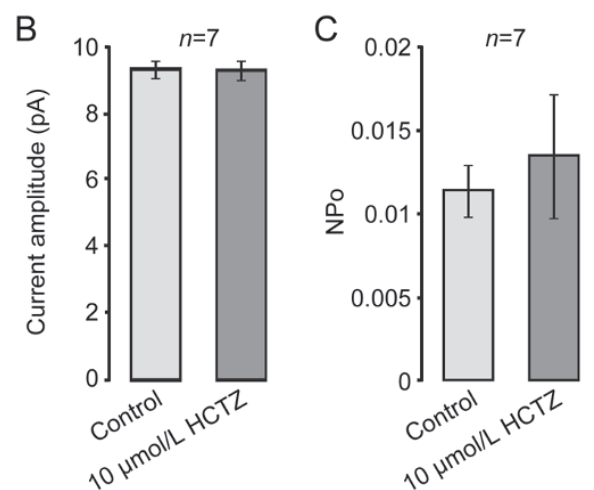

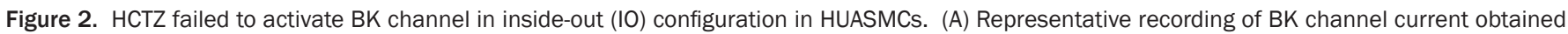

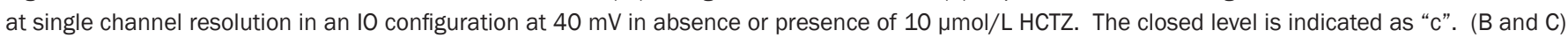

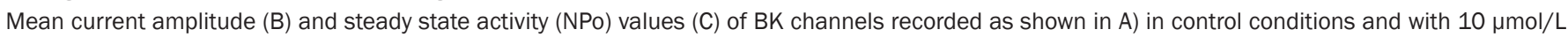
HCTZ ( $n=7$ patches from 3 umbilical cord donors). No statistically significant differences were observed (paired $t$ test, $P>0.05$ ). 
A

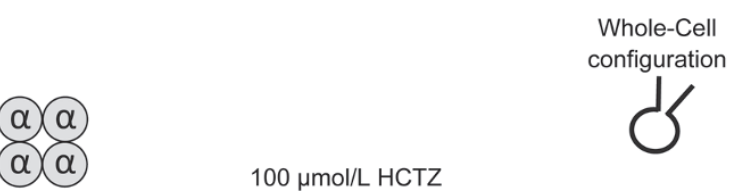

Control

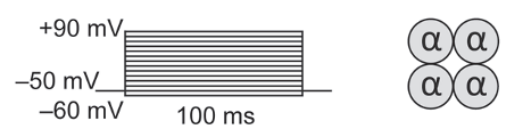

$100 \mu \mathrm{mol} / \mathrm{L} \mathrm{HCTZ}$
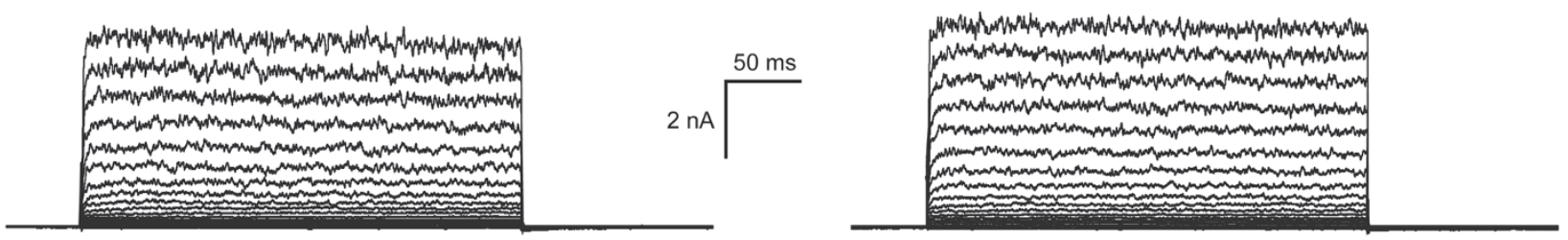

B

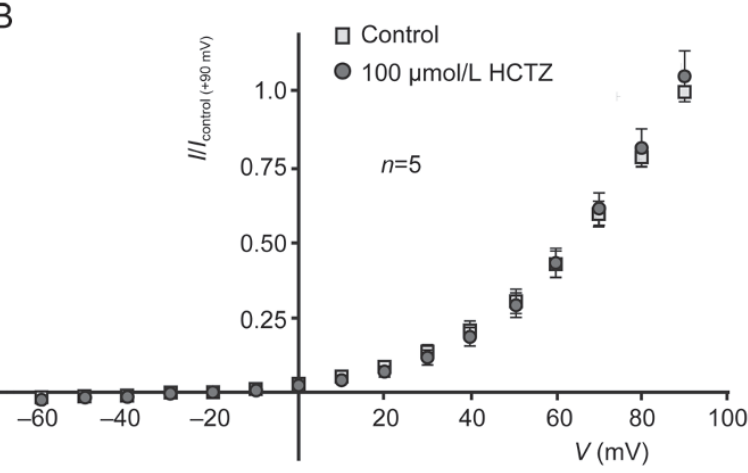

C

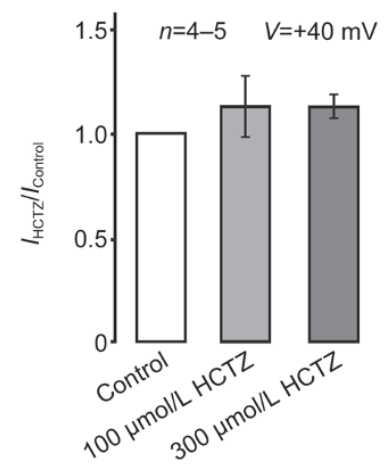

Figure 3. HCTZ failed to modulate BK channel activity in the absence of regulatory $\beta$-subunits in HEK293T cells. (A) Superimposed representative WCR currents of BK channels expressed in HEK293T cells without the $\beta_{1}$-subunit, before (left) and after 15 min of $100 \mu \mathrm{mol} / \mathrm{L} \mathrm{HCTZ} \mathrm{perfusion} \mathrm{(right).} \mathrm{The}$ currents were elicited in response to $10 \mathrm{mV}$ voltage steps from $-60 \mathrm{mV}$ to $+90 \mathrm{mV}$ from a holding potential of $-50 \mathrm{mV}$. (B) $I-\mathrm{V}$ curves corresponding to the control conditions and $15 \mathrm{~min}$ of $100 \mu \mathrm{mol} / \mathrm{L} \mathrm{HCTZ}$ perfusion. The BK channel currents were normalized to the ones elicited by the $+90 \mathrm{mV}$ voltage

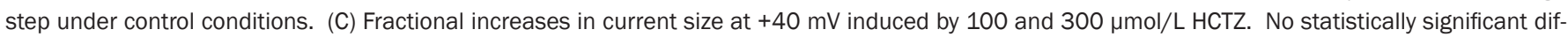
ferences were observed (ANOVA, Ranks test, $P>0.05$ ).

heterologous system in more detail. Thus, the effect of the diuretic on the whole-cell BK current resulting from $a+\beta_{1}$ expression was examined at 10, 30, 100 and $300 \mu \mathrm{mol} / \mathrm{L}$. HCTZ induced a left-shift in the $I-V$ curves (Figure 4A, B; $P<0.05)$. Consistently, higher increases in fractional activity were observed at less depolarized voltages, at which the basal open probability is lower (Figure $4 \mathrm{C}$ ). Additionally, we plotted the concentration-response curve at all membrane potentials where the HCTZ-induced current increase was statistically significant (from +20 to $+90 \mathrm{mV}$ ) and fitted these data to a Hill equation. The current-enhancing effect of HCTZ presents an $\mathrm{EC}_{50}$ of $28.4 \mu \mathrm{mol} / \mathrm{L}(95 \% \mathrm{CI}: 10.4-77.7 \mu \mathrm{mol} / \mathrm{L})$ measured at $+40 \mathrm{mV}$, rendering a $\mathrm{p}_{2}=4.546 \pm 0.211(n: 5-8$, Figure $4 \mathrm{D})$. Moreover, both $\mathrm{pD}_{2}$ and the Hill slope of HCTZ activation were voltage independent (Figures $4 \mathrm{E}$ and $4 \mathrm{~F}$, respectively, $P>0.05)$. These results showed that HCTZ increased the BK current when the channel emulates the basic composition of this channel in HUASMCs ${ }^{[32]}$.

The results, showed above on native HUASMCs demonstrated that cellular integrity is essential for HCTZ-induced BK channel activation (Figure 2). To validate these findings, we determined whether cellular integrity is required for the HCTZ-induced activation of recombinant BK channels containing the $\beta_{1}$-subunit in a mammalian expression system. First, we obtained macroscopic currents (in the IO configura- tion) evoked from $\beta_{1}$-containing BK channels in the presence or absence of HCTZ in HEK cells. HCTZ had no effect on BK current at any examined concentration (10,30 and $100 \mu \mathrm{mol} / \mathrm{L})$ (Figure $5 \mathrm{C}, P>0.05$ ). Figure $5 \mathrm{~B}$ shows the $I-V$ relationships obtained for each condition. The negative results from the IO configuration could indicate that this diuretic requires cell integrity to activate the BK channel. However, considering the poor lipophilicity of HCTZ ( $\log$ P: - 0.07$)$, these results could also indicate that the region responsible for BK channel activation is located on the extracellular side of the channel. To clarify this issue, we examined the effect of HCTZ on recombinant BK channels containing the $\beta_{1}$-subunit in HEK293T cells at single channel resolution using the cell-attached (CA) configuration. A concentration of $100 \mu \mathrm{mol} / \mathrm{L} \mathrm{HCTZ} \mathrm{increased}$ the steady state BK channel open probability at a $40 \mathrm{mV}$ membrane potential. Figure 5D shows a typical stability plot of channel activation, where the open probability (expressed as NPo) was calculated every $30 \mathrm{~s}$ and plotted as a function of the recording time. HCTZ slowly increased the NPo of the BK channel, reaching maximal steady state activation after approximately $15 \mathrm{~min}$ of HCTZ perfusion. Typical recordings of BK channel activity before and after diuretic perfusion are included in Figure 5D. HCTZ induced a significant 4.72 $\pm 1.24-$ fold increase in the NPo values (Figure $5 \mathrm{E}, P<0.05, n=3$ ). This change in channel activity recorded in the CA configuration 
A
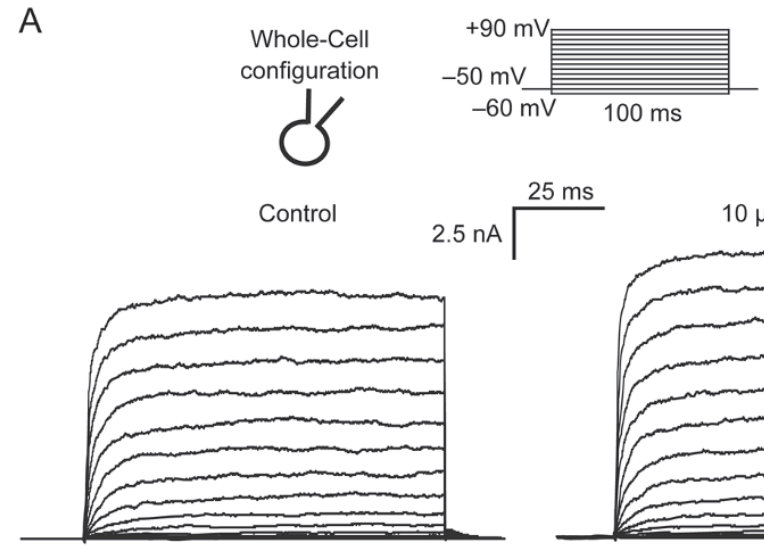

$25 \mathrm{~ms}$

$10 \mu \mathrm{mol} / \mathrm{L} \mathrm{HCTZ}$
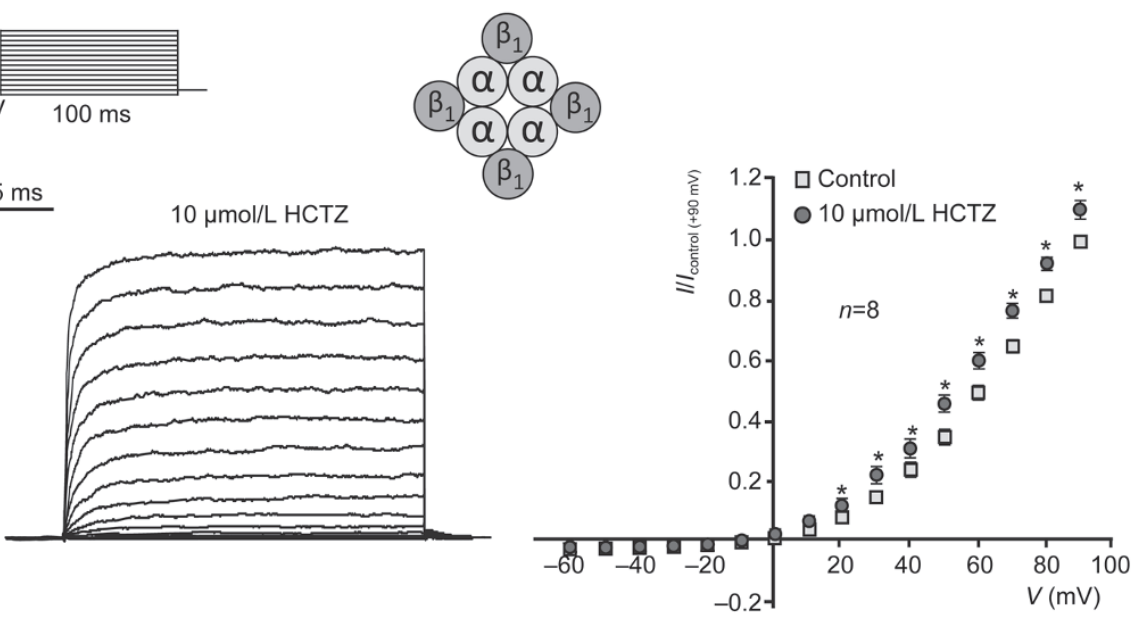

B

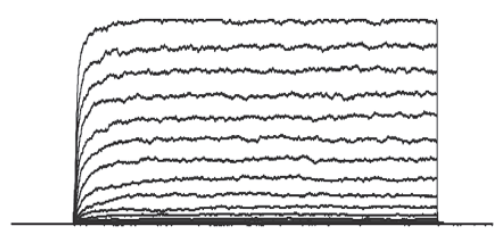

Control

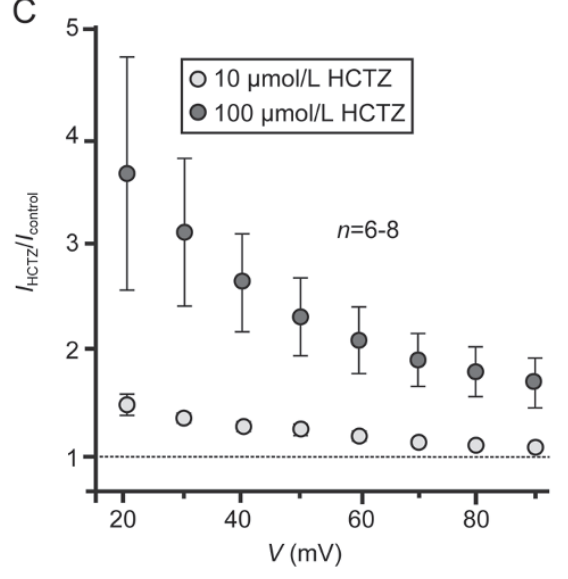

D

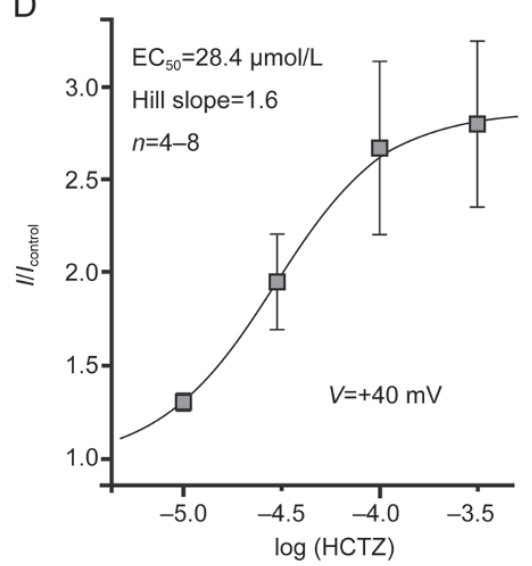

$100 \mu \mathrm{mol} / \mathrm{L} \mathrm{HCTZ}$
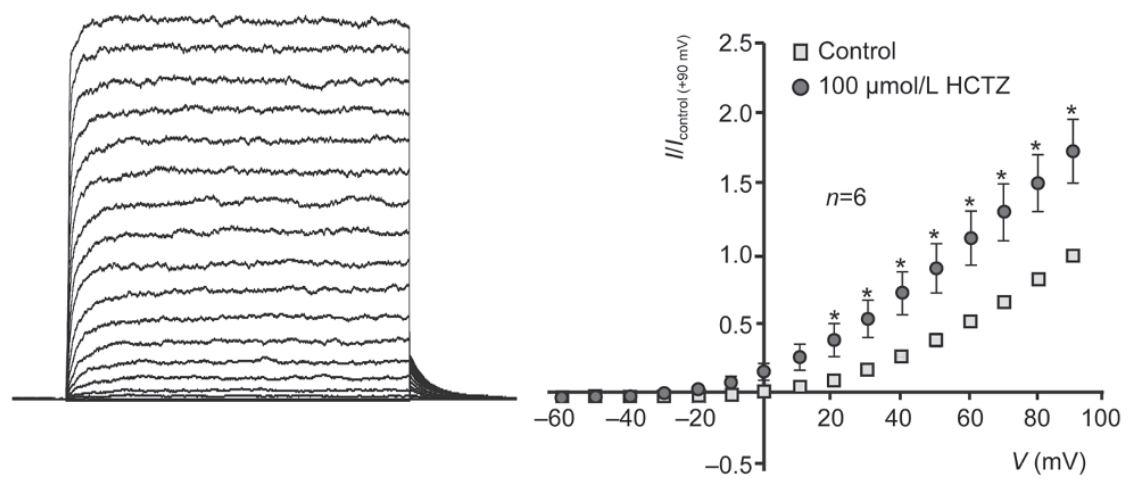

E

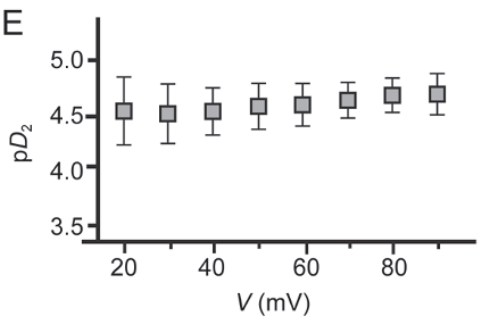

F

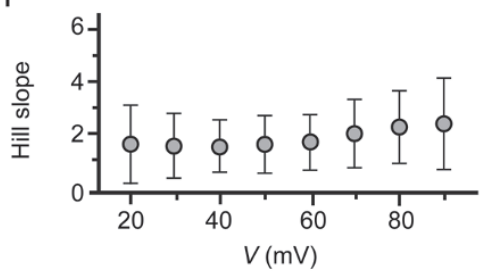

Figure 4. HCTZ activates recombinant BK channels expressed with regulatory $\beta_{1}$-subunits in HEK293T cells in a concentration-dependent manner. Superimposed representative WCR currents of BK channels expressed in HEK293T cells with the $\beta_{1}$-subunit, before (left) and after 15 min of 10 (A) and $100 \mu \mathrm{mol} / \mathrm{L}$ (B) HCTZ perfusion (middle). The currents were elicited in response to $10 \mathrm{mV}$ voltage steps from $-60 \mathrm{mV}$ to $+90 \mathrm{mV}$ from a holding potential of $-50 \mathrm{mV}$. Mean current vs voltage (I-V) curves corresponding to the control conditions and $15 \mathrm{~min}$ of 10 and $100 \mu \mathrm{mol} / \mathrm{L} \mathrm{HCTZ} \mathrm{perfusion} \mathrm{(right).}$ The BK channel currents were normalized to the ones elicited by the $+90 \mathrm{mV}$ voltage step under control conditions. The symbol * indicates statistically significant difference from control (paired $t$ test, $P<0.05$ ). (C) Fractional increases in current size at different voltages $(n=6-8)$ induced by 10 and 100 $\mu \mathrm{mol} / \mathrm{L} \mathrm{HCTZ}$. (D) Concentration-dependence of HCTZ-induced BK channel activation. Currents were measured at $+40 \mathrm{mV}$ and a single concentration of HCTZ shown was tested in each cell. Data points were fitted by a Hill function (solid line). Half-maximal effective concentration (EC $\left.\mathrm{C}_{50}\right): 28.4 \mu$ mol/L (95\%Cl: $10.4-77.7 \mu \mathrm{mol} / \mathrm{L})$, Hill slope: 1.6 (95\% Cl: 0.586 to 2.781$)$. (E, F) Voltage-dependence of the $\mathrm{EC}_{50}$, expressed as $\mathrm{p} \mathrm{D}_{2}( \pm \mathrm{SEM})$, and Hill Slope $( \pm$ SEM) of BK channel activation. Each value was obtained as in D. No statistically significant differences were observed in both parameters $(F$ method, $P>0.05$ ). 
A
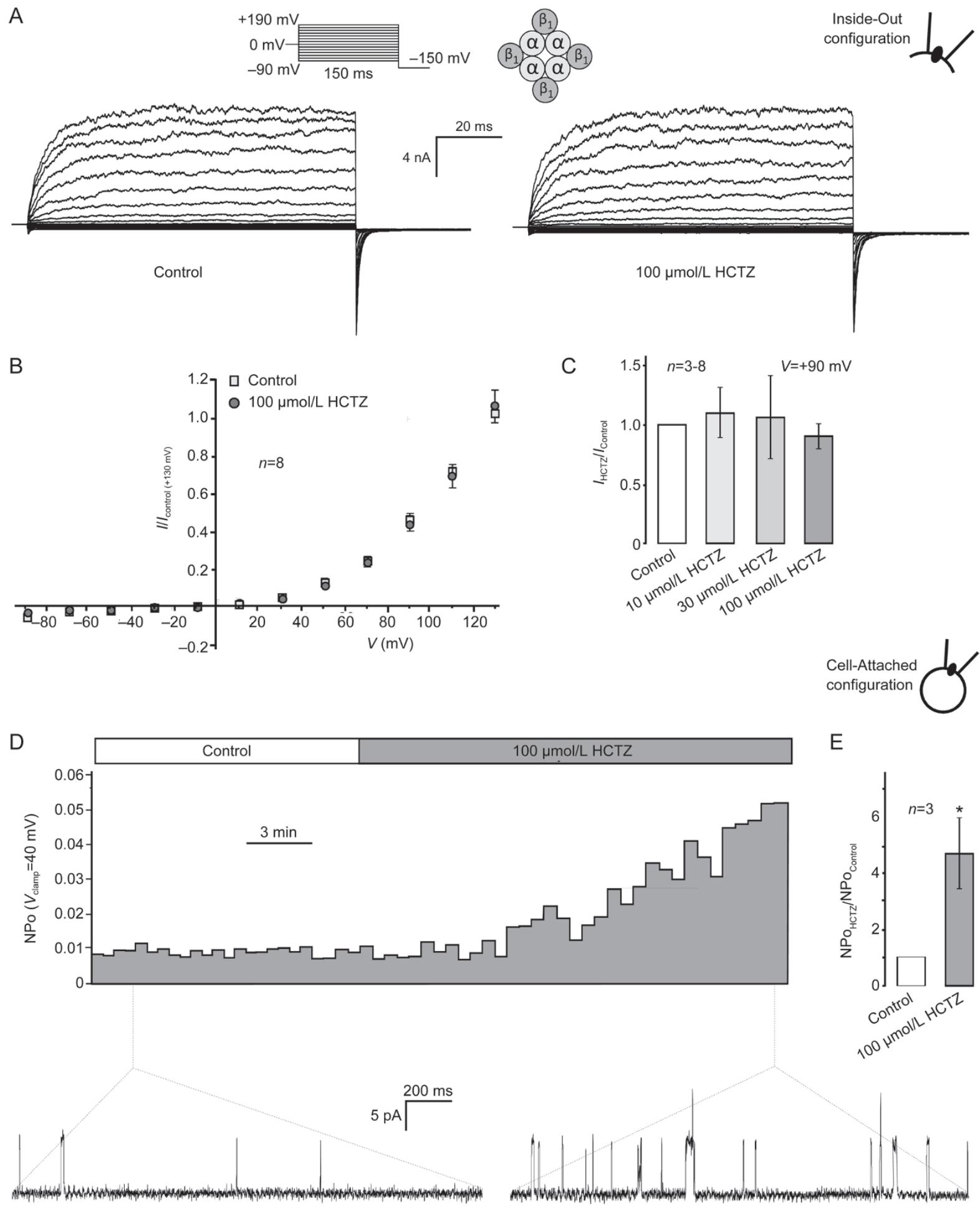

$\mathrm{E}$
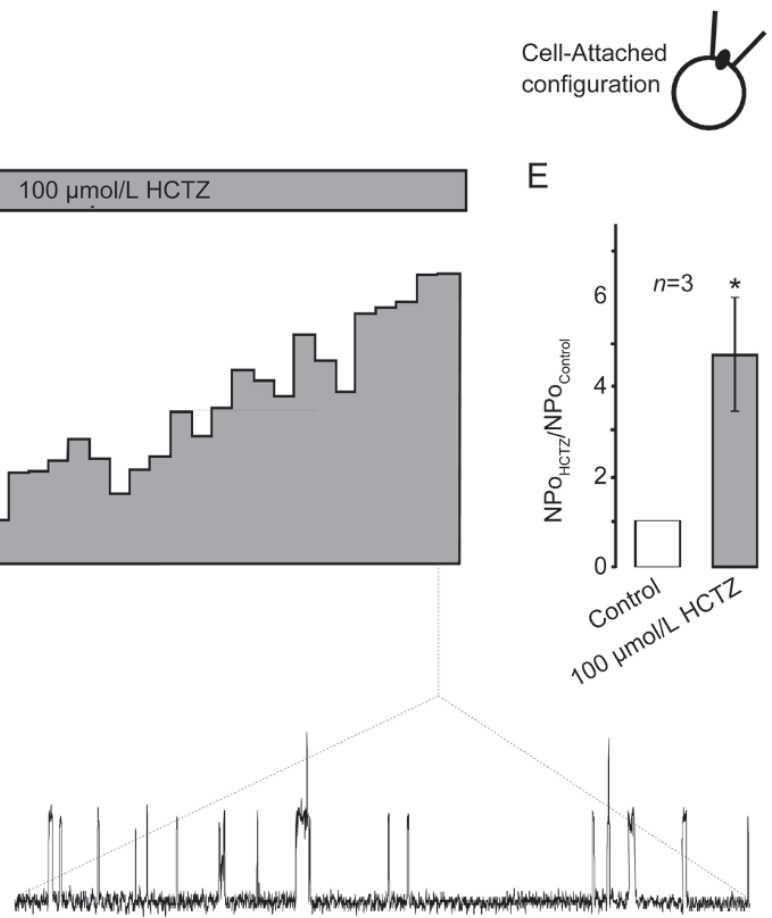

Figure 5. HCTZ requires cell integrity to activate recombinant BK channels expressed with the $\beta_{1}$-subunit in HEK293T cells. (A) Superimposed representative cell-free 10 currents of BK channels expressed in HEK293T cells with the $\beta_{1}$-subunit, before (left) and after $15 \mathrm{~min}$ of $100 \mu \mathrm{mol} / \mathrm{L} \mathrm{HCTZ} \mathrm{perfu-}$ sion (right). The currents were elicited in response to $20 \mathrm{mV}$ voltage steps from $-90 \mathrm{mV}$ to $+130 \mathrm{mV}$ from a holding potential of $0 \mathrm{mV}$. (B) $I-V$ curves corresponding to the control conditions and $15 \mathrm{~min}$ of $100 \mu \mathrm{mol} / \mathrm{L} \mathrm{HCTZ}$ perfusion recorded as $\mathrm{A}$. The BK channel currents were normalized to the ones elicited by the $+130 \mathrm{mV}$ voltage step under control conditions. (C) Fractional increases in current size at $+90 \mathrm{mV}$ induced by 10,30 and $100 \mu \mathrm{mol} / \mathrm{L}$ HCTZ. No statistically significant differences were observed (ANOVA, Ranks test, $P>0.05$ ). (D) Temporal course of $100 \mu \mathrm{mol} / \mathrm{L} \mathrm{HCTZ} \mathrm{effect} \mathrm{on} \mathrm{BK} \mathrm{chan-}$ nels expressed in HEK293T cells with the $\beta_{1}$-subunit recorded in the Cell-Attached configuration at $40 \mathrm{mV}$. Single-channel activity was expressed as $\mathrm{NPo}$, which values were calculated every $30 \mathrm{~s}$ and plotted as a function of recording time. The inset corresponds to representative traces of BK channel

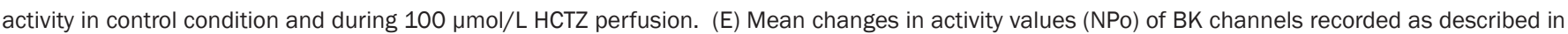

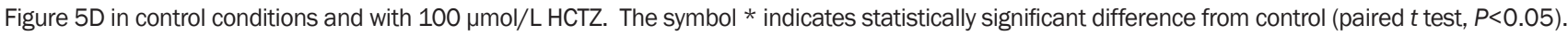


can only occur through indirect mechanisms or the direct activity of membrane permeable drugs that can access the ion channel present in the patch only after crossing the plasma membrane from the bath solution to the cytoplasmic milieu. The results in the IO configuration enabled the rejection of the latter mechanism, confirming the cell integrity requirement for BK channel activation by HCTZ.

\section{Discussion}

The present study represents the first use of patch-clamp electrophysiology to evaluate the effect of HCTZ, a thiazide diuretic, on BK currents in a VSMC. Evaluating the effect of HCTZ on whole-cell BK currents in both native and heterologous systems demonstrated that 1) HCTZ activates the BK channel present in human VSMCs, confirming this channel as a probable target for the diuretic's vasodilator effect; 2) The presence of the $\beta_{1}$ accessory subunit is necessary for HCTZ to activate BK channels; and 3) HCTZ-induced BK channel activation requires cellular integrity.

The reduction in peripheral vascular resistance is a common property of thiazide-like diuretics that is not related to the NCC blockage ${ }^{[2]}$. However, evidence suggests that different thiazides do not share the same mechanisms for the induction of vasodilation ${ }^{[5,8]}$. In particular, Calder et al previously proposed the HCTZ-induced BK channel activation ${ }^{[5,8]}$, as a probable mechanism to explain the dilation of guinea pig mesenteric and human subcutaneous arteries through the in vitro application of HCTZ. Indeed, in the guinea pig model, the relaxation effect of this diuretic was independent of the presence or absence of the endothelium ${ }^{[8]}$. Additionally, HCTZ induced $\mathrm{Rb}^{86}$ efflux ${ }^{[12]}$ and vessel relaxation, both actions being largely blocked by the selective BK channel blocker iberiotoxin $^{[8]}$. Subsequently, Pickkers et al ${ }^{[7]}$, also studying the mesenteric guinea pig artery, demonstrated that HCTZ reduced the increase in intracellular $\mathrm{Ca}^{2+}$ concentration evoked by norepinephrine without affecting the $\mathrm{Ca}^{2+}$ release from intracellular $\mathrm{Ca}^{2+}$ stores. These authors speculated that HCTZ activates BK channels, and this activation, acting as a hyperpolarizing mechanism, reduces the $\mathrm{Ca}^{2+}$ influx through the VOCC. Collectively, these previous studies have suggested that BK channel activation contributes to HCTZ-induced vasodilation. However, whether HCTZ increases the smooth muscle BK potassium current through direct or indirect interactions with this channel protein has remained unknown. Addressing this dichotomy acquired particular relevance in light of studies showing that BK channel activity could be enhanced by vasodilator substances acting directly on the channel protein ${ }^{[30,43]}$ and via intracellular signaling and shuttling of BK proteins between intracellular organelles and the plasmalemma ${ }^{[16]}$. In the present study, using HUASMCs, we propose that HCTZ activates the BK channel not through a direct interaction between the diuretic and the channel protein but rather through an indirect mechanism that requires cell integrity. This idea is sustained by the fact that BK current enhancement was observed only in whole-cell (Figures 1 and 4) and cell-attached configurations (Figure 5D), while in the cell-free inside-out configuration (Figures 2 and 5A), neither the unitary channel conductance nor its open probability were modified by HCTZ. The similar outcomes between studies using vascular smooth muscle and HEK cells strongly suggests that the indirect mediator(s) of HCTZ-thiazide interaction on BK channels is conserved between two different cell types.

Several mechanisms can be proposed to explain how HCTZ indirectly alters channel activity. There is a growing list of interacting proteins and mediators associated with the C-terminus of the BK a-subunit. Moreover, these molecules depend on each particular cellular environment, a-subunit splicing variants, and co-expression with auxiliary subunits ${ }^{[44]}$. This list can include different intracellular ions (such as $\mathrm{Mg}^{2+}$, $\mathrm{Ca}^{2+}$ and $\mathrm{H}^{+}$); protein kinases (such as PKA, PKC, PKG, PyK2 and FAK); intracellular mediators (such as GMPc, $\mathrm{PIP}_{2}$ and arachidonic acid); receptors that regulate channel activity independent of downstream pathways (such as $\beta_{2}$-adrenergic and thromboxane $\mathrm{A}_{2}$ receptor); and structural cell proteins (eg, caveolin and actin $)^{[44]}$. It has been hypothesized that HCTZinduced increases in intracellular $\mathrm{pH}$ in VSMCs (via carbonic anhydrase inhibition) is responsible for BK channel activation $^{[45]}$. This hypothesis contrasts with the low antihypertensive efficacy of specific carbonic anhydrase inhibitors ${ }^{[1]}$, such as acetozolamide. The present data also contrast with the " $\mathrm{pH}$ hypothesis": we demonstrated that HCTZ action is conserved under conditions in which changes in $\mathrm{pH}_{\mathrm{i}}$ in the electrode solution (ie, WCR configuration) were precluded by strong buffering. Thus, it is highly likely that the mediators of HCTZ BK channel activation in HUASMCs are membrane bound (eg, PKC translocation and BK subunit shuttling).

The experiments on BK channel expressed in HEK293T cells further clarify the mechanism implicated in channel activation by HCTZ. In the whole cell configuration, HCTZ produces a concentration-dependent BK current enhancement with an $\mathrm{EC}_{50}$ value of $28 \mu \mathrm{mol} / \mathrm{L}$ (Figure 4D). Interestingly, this concentration was similar to that measured by Calder et al ${ }^{[8]}$ in ex vivo experiments and the concentration used in previous studies $^{[5-7,12,45]}$. Additionally, the $\mathrm{EC}_{50}$ and Hill slope values were both voltage-independent (Figures $4 \mathrm{E}$ and $4 \mathrm{~F}$ ), indicating that putative intracellular mediators involved in the indirect effect of HCTZ, are insensitive to the membrane voltage field and likely membrane associated (similar to observations in HUASMCs, and the effect is lost in IO patches).

The physiological and pharmacological modulation of the BK channel, including by HCTZ, is variable among different cell types ${ }^{[5,19]}$. The differential expression of the auxiliary $\beta$-subunits can explain, in part, this variability, as these subunits have been reported to interact with the a-subunit, promoting or decreasing the effects of endogenous or exogenous substances on channel activity ${ }^{[19,30,31,43]}$. Moreover, the expression of these four subtypes is different among tissues ${ }^{[21,46,47]}$ and even among different arteries from the same species ${ }^{[48]}$. Thus, $\beta$-subunits would be key structures to obtain a tissueselective pharmacological modulation of the BK channel ${ }^{[19]}$. In the case of HCTZ, we demonstrated that the presence of the $\beta_{1}$-subunit, which is primarily expressed in smooth muscle 
cells, is a requirement for BK channel activation (Figures 3 and 4). This result also explains why Tricarico et al did not observe BK channel current enhancement by HCTZ in skeletal muscle cells $^{[37]}$, where the channel is expressed without any $\beta$-subunit, and in HEK cells transfected only with the a-subunit ${ }^{[36]}$. Collectively, the present results, which include both the complexity of the native cells and the simplicity of the heterologous system, demonstrated that the activation of the BK channels by HCTZ is effective in human vascular cells, likely involving an intracellular factor, and shows selectivity for the $\alpha-\beta_{1}$-complex without affecting the channel formed only by four $\alpha$-subunits.

Notably, the HCTZ effect depends on the species employed for the experimental procedures ${ }^{[5]}$. Particularly, in human vasculature, the activation of a $\mathrm{K}^{+}$channel by thiazide-like diuretics was supported by previous in vivo and ex vivo experiments. HCTZ relaxes human subcutaneous and internal mammary arteries, and this effect is blocked by charybdotoxin, which inhibits BK and intermediate $\mathrm{Ca}^{2+}$-activated channel ${ }^{[5,6]}$. Moreover, tetraethylammonium (a nonselective $\mathrm{K}^{+}$channels blocker) avoids the in vivo vasodilator effect of HCTZ in the human forearm artery ${ }^{[4]}$. Here, we demonstrated BK channel activation induced by HCTZ in human umbilical artery smooth muscle cells. Taken together, these results suggest that HCTZ-induced BK activation is a relevant process in human vasculature and support the idea that this activation is likely involved in the vasorelaxant effect of this commonly used antihypertensive drug.

In conclusion, we propose that BK channel activation by HCTZ could contribute to its vasodilator effects, an action resulting from $\mathrm{HCTZ}$ acting on the SMC itself, while requiring cell integrity but not direct binding to the BK channel proteins. Thus, the present experimental approach represents significant progress in determining the molecular target or signaling pathway responsible for HCTZ-induced SMC relaxation. Moreover, we speculate that BK channel activation in vascular SMCs may be, at least partially, responsible for the efficacy of hypertension treatment with thiazide diuretics. Finally, we provide additional evidence for the growing acceptance of using the BK channel as a target for hypertension treatment, focusing on the $\beta_{1}$-subunit as the key to obtaining selectivity in VSMCs.

\section{Acknowledgments}

The authors gratefully acknowledge the excellent technical assistance of Mr Ángel Flores CASTRO and Ms Julia de SANTIS. The authors would also like to thank Dr Miriam MACHUCA and the staff of the Hospital Gutierrez from La Plata for the collection of umbilical cords. This work was financially supported through a grant from the Agencia Nacional de Promoción Científica y Tecnológica (ANPCYT), Argentina (PICT 2014-0603). The authors are grateful to Dr Alejandro REBOLLEDO and Nicolás ENRIQUE for critical feedback on the manuscript.

\section{Author contribution}

Pedro MARTíN designed the research, performed the research, analyzed the data and drafted the manuscript; Melisa
MONCADA performed the research; Guruprasad KUNTAMALLAPPANAVAR drafted the manuscript; Alex M DOPICO revised the manuscript for important intellectual content; and Verónica MILESI designed the research and drafted the manuscript.

\section{Abbreviations}

HCTZ: hydrochlorothiazide; NCC: $\mathrm{Na}^{+} / \mathrm{Cl}^{-}$cotransporter; BK channel: large conductance voltage- and $\mathrm{Ca}^{2+}$-dependent potassium channel; VOCCs: voltage-operated calcium channels; VSMCs: vascular smooth muscle cells; HUAs: human umbilical arteries; HUASMCs: human umbilical artery smooth muscle cells; DM: dissociation medium; DMEM: Dulbecco's modified Eagle's medium; FBS: fetal bovine serum; eGFP: enhanced green fluorescent protein; IO: inside-out configuration; Po: open probability; BS: bath solution; WCR: whole-cell recording; 4-AP: 4-aminopirydine; $I-V$ : current-voltage relationship; DMSO: dimethyl sulfoxide; $\mathrm{K}_{\mathrm{v}}$ : voltage-dependent $\mathrm{K}^{+}$channels

\section{References}

1 James PA, Oparil S, Carter BL, Cushman WC, Dennison-Himmelfarb C, Handler J, et al. 2014 evidence-based guideline for the management of high blood pressure in adults: report from the panel members appointed to the Eighth Joint National Committee (JNC 8). JAMA 2014; 311: $507-20$.

2 Duarte JD, Cooper-DeHoff RM. Mechanisms for blood pressure lowering and metabolic effects of thiazide and thiazide-like diuretics. Expert Rev Cardiovasc Ther 2010; 8: 793-802.

3 van Brummelen P, Man IVA, Schalekamp MA. Hemodynamic changes during long-term thiazide treatment of essential hypertension in responders and nonresponders. Clin Pharmacol Ther 1980; 27: 32836.

4 Pickkers P, Hughes AD, Russel FG, Thien T, Smits P. Thiazide-induced vasodilation in humans is mediated by potassium channel activation. Hypertension 1998; 32: 1071-6.

5 Calder JA, Schachter M, Sever PS. Vasorelaxant actions of thiazides and related drugs. Br J Pharmacol 1992: 105: 307P.

6 Afsar S, Hemsinli D, Ozyazgan S, Akkan AG, Arslan C. The effects of potassium channels in human internal mammary artery. Pharmacology 2016; 97: 72-7.

7 Pickkers $P$, Hughes AD. Relaxation and decrease in $\left[\mathrm{Ca}^{2+}\right]_{i}$ by hydrochlorothiazide in guinea-pig isolated mesenteric arteries. $\mathrm{Br} J$ Pharmacol 1995; 114: 703-7.

8 Calder JA, Schachter M, Sever PS. Ion channel involvement in the acute vascular effects of thiazide diuretics and related compounds. J Pharmacol Exp Ther 1993; 265: 1175-80.

9 Zhu Z, Zhu S, Liu D, Cao T, Wang L, Tepel M. Thiazide-like diuretics attenuate agonist-induced vasoconstriction by calcium desensitization linked to Rho kinase. Hypertension 2005; 45: 233-9.

10 Lake C, Ziegler M, Coleman M, IJ K. Hydrochlorothiazide-induced sympathetic hyperactivity in hypertensive patients. Clin Pharmacol Ther 1979; 26: 428-32.

11 Wilson I, Freis E. Relationship between plasma and extracellular fluid volume depletion and the antihypertensive effect of chlorothiazide. Circulation 1959; 20: 1028-36.

12 Calder JA, Schachter M, Sever PS. Potassium channel opening properties of thiazide diuretics in isolated guinea pig resistance arteries. J Cardiovasc Pharmacol 1994; 24: 158-64.

13 Mironneau J, Savineau JP, Mironneau C. Compared effects of indapamide, hydrochlorothiazide and chlorthalidone on electrical and me- 
chanical activities in vascular smooth muscle. Eur J Pharmacol 1981; 75: 109-13.

14 Nelson M, Brayden J. Regulation of arterial tone by calcium-dependent $\mathrm{K}^{+}$channels and ATP-sensitive $\mathrm{K}^{+}$channels. Cardiovasc Drugs Ther 1993; 7 Suppl 3: 605-10.

15 Ledoux J, Werner M, Brayden J, Nelson M. Calcium-activated potassium channels and the regulation of vascular tone. Physiology (Bethesda) 2006; 21: 69-78.

16 Jaggar J, Porter V, Lederer W, Nelson M. Calcium sparks in smooth muscle. Am J Physiol Cell Physiol 2000; 278: C235-56.

$17 \mathrm{Cox} \mathrm{RH}$. Changes in the expression and function of arterial potassium channels during hypertension. Vasc Pharmacol 2002; 38: 13-23.

18 Eichhorn B, Dobrev D. Vascular large conductance calcium-activated potassium channels: functional role and therapeutic potential. Naunyn Schmiedebergs Arch Pharmacol 2007; 376: 145-55.

19 Torres YP, Granados ST, Latorre R. Pharmacological consequences of the coexpression of BK channel alpha and auxiliary beta subunits. Front Physiol 2014; 5: 383.

20 Xia XM, Ding JP, Lingle CJ. Molecular basis for the inactivation of $\mathrm{Ca}^{2+}$ and voltage-dependent BK channels in adrenal chromaffin cells and rat insulinoma tumor cells. J Neurosci 1999; 19: 5255-64.

21 Brenner R, Jegla TJ, Wickenden A, Liu Y, Aldrich RW. Cloning and functional characterization of novel large conductance calcium-activated potassium channel beta subunits, hKCNMB3 and hKCNMB4. J Biol Chem 2000; 275: 6453-61.

22 Behrens R, Nolting A, Reimann F, Schwarz M, Waldschutz R, Pongs 0 . hKCNMB3 and hKCNMB4, cloning and characterization of two members of the large-conductance calcium-activated potassium channel beta subunit family. FEBS Lett 2000; 474: 99-106.

23 Uebele VN, Lagrutta A, Wade T, Figueroa DJ, Liu Y, McKenna E, et al. Cloning and functional expression of two families of beta-subunits of the large conductance calcium-activated $\mathrm{K}^{+}$channel. J Biol Chem 2000; 275: 23211-8.

24 Wallner M, Meera P, Toro L. Molecular basis of fast inactivation in voltage and $\mathrm{Ca}^{2+}$-activated $\mathrm{K}^{+}$channels: a transmembrane betasubunit homolog. Proc Natl Acad Sci U S A 1999; 96: 4137-42.

25 Knaus HG, Folander K, Garcia-Calvo M, Garcia ML, Kaczorowski GJ, Smith $\mathrm{M}$, et al. Primary sequence and immunological characterization of beta-subunit of high conductance $\mathrm{Ca}^{2+}$-activated $\mathrm{K}^{+}$channel from smooth muscle. J Biol Chem 1994; 269: 17274-8.

26 Gonzalez C, Baez-Nieto D, Valencia I, Oyarzun I, Rojas P, Naranjo D, et al. $\mathrm{K}^{+}$channels: function-structural overview. Compr Physiol 2012; 2: 2087-149.

27 Sweet TB, Cox DH. Measuring the influence of the $\mathrm{BK}_{\mathrm{ca}}\{$ beta\}1 subunit on $\mathrm{Ca}^{2+}$ binding to the BKCa channel. J Gen Physiol 2009; 133: $139-50$.

28 Latorre R, Brauchi S. Large conductance $\mathrm{Ca}^{2+}$-activated $\mathrm{K}^{+}(\mathrm{BK})$ channel: activation by $\mathrm{Ca}^{2+}$ and voltage. Biol Res 2006; 39: 385401.

29 Knaus HG, Garcia-Calvo M, Kaczorowski GJ, Garcia ML. Subunit composition of the high conductance calcium-activated potassium channel from smooth muscle, a representative of the mSlo and slowpoke family of potassium channels. J Biol Chem 1994; 269: 3921-4.

30 Bukiya AN, Liu J, Toro L, Dopico AM. Beta1 (KCNMB1) subunits mediate lithocholate activation of large-conductance $\mathrm{Ca}^{2+}$-activated $\mathrm{K}^{+}$channels and dilation in small, resistance-size arteries. Mol Pharmacol 2007; 72: 359-69.

31 Bukiya AN, Vaithianathan T, Toro L, Dopico AM. Channel beta24 subunits fail to substitute for beta1 in sensitizing BK channels to lithocholate. Biochem Biophys Res Commun 2009; 390: 995-1000.

32 Martín P, Moncada M, Enrique N, Asuaje A, Valdez Capuccino JM, Gonzalez C, et al. Arachidonic acid activation of BKCa (Slo1) channels associated to the $\beta 1$-subunit in human vascular smooth muscle cells. Pflugers Arch 2013; 466: 1779-92.

33 Hoshi T, Tian Y, Xu R, Heinemann SH, Hou S. Mechanism of the modulation of BK potassium channel complexes with different auxiliary subunit compositions by the omega-3 fatty acid DHA. Proc Natl Acad Sci U S A 2013; 110: 4822-7.

34 Fernandez-Fernandez JM, Tomas M, Vazquez E, Orio P, Latorre R, Senti M, et al. Gain-of-function mutation in the KCNMB1 potassium channel subunit is associated with low prevalence of diastolic hypertension. J Clin Invest 2004; 113: 1032-9.

35 Yang Y, Li PY, Cheng J, Mao L, Wen J, Tan XQ, et al. Function of BKCa channels is reduced in human vascular smooth muscle cells from Han Chinese patients with hypertension. Hypertension 2013; 61: 519-25.

36 Tricarico D, Mele A, Calzolaro S, Cannone G, Camerino GM, Dinardo $\mathrm{MM}$, et al. Emerging role of calcium-activated potassium channel in the regulation of cell viability following potassium ions challenge in HEK293 cells and pharmacological modulation. PLoS One 2013; 8: e69551.

37 Tricarico D, Mele A, Conte Camerino D. Carbonic anhydrase inhibitors ameliorate the symptoms of hypokalaemic periodic paralysis in rats by opening the muscular $\mathrm{Ca}^{2+}$-activated- $\mathrm{K}^{+}$channels. Neuromuscul Disord 2006; 16: 39-45.

38 Klockner U. Intracellular calcium ions activate a low-conductance chloride channel in smooth-muscle cells isolated from human mesenteric artery. Pflugers Arch 1993; 424: 231-7.

39 Hamill OP, Marty A, Neher E, Sakmann B, Sigworth FJ. Improved patch-clamp techniques for high-resolution current recording from cells and cell-free membrane patches. Pflugers Arch 1981; 391: 85100.

40 Martin P, Enrique N, Roldán Palomo AR, Rebolledo A, Milesi V. Bupivacaine inhibits large conductance, voltage- and $\mathrm{Ca}^{2+}$ - activated $\mathrm{K}^{+}$channels in human umbilical artery smooth muscle cells. Channels (Austin) 2012; 6: 174-80.

41 Martin P, Rebolledo A, Palomo AR, Moncada M, Piccinini L, Milesi V. Diversity of potassium channels in human umbilical artery smooth muscle cells: a review of their roles in human umbilical artery contraction. Reprod Sci 2014; 21: 432-41.

42 Milesi V, Raingo J, Rebolledo A, Grassi de Gende AO. Potassium channels in human umbilical artery cells. J Soc Gynecol Investig 2003; 10: 339-46.

43 Bukiya A, McMillan J, Fedinec AL PS, Miller DD, Leffler CW, Parrill AL, et al. Cerebrovascular dilation via selective targeting of the cholane steroid-recognition site in the BK channel $\beta 1$-subunit by a novel nonsteroidal agent. Mol Pharmacol 2013; 83: 1030-44.

44 Lu R, Alioua A, Kumar Y, Eghbali M, Stefani E, Toro L. MaxiK channel partners: physiological impact. J Physiol 2006; 570: 65-72.

45 Pickkers P, Garcha RS, Schachter M, Smits P, Hughes AD. Inhibition of carbonic anhydrase accounts for the direct vascular effects of hydrochlorothiazide. Hypertension 1999; 33: 1043-8.

46 Brenner R, Perez GJ, Bonev AD, Eckman DM, Kosek JC, Wiler SW, et al. Vasoregulation by the beta1 subunit of the calcium-activated potassium channel. Nature 2000; 407: 870-6.

47 Behrens R, Nolting A, Reimann F, Schwarz M, Waldschütz R, Pongs O. hKCNMB3 and hKCNMB4, cloning and characterization of two members of the large-conductance calcium-activated potassium channel beta subunit family. FEBS Lett 2000 2000; 474: 99-106.

48 Kuntamallappanavar G, Bisen S, Bukiya AN, Dopico AM. Differential distribution and functional impact of BK channel beta1 subunits across mesenteric, coronary, and different cerebral arteries of the rat. Pflügers Arch 2016; 469: 263-77. 